VIOLETTA SKRODZKA

\title{
Organic agricultural products in Europe and USA
}

Violetta Skrodzka, Ph.D. Gdynia Maritime University Faculty of Entrepreneurship and Quality Science

\section{Introduction}

The popularity of organic products is constantly increasing. This is confirmed by a number of specialized studies conducted on organic food and their traditional counterparts and the growing range of retailers. In the 1990s, there were difficulties in obtaining ecological products both in the United States and Europe.

The claim that organic products are more nutritious and safer for human health than conventional food is currently firmly established. This position has not been changed by varied research results published by the researchers. The conviction of buyers about the superiority of the organic product over the conventional one is due to the growing public awareness formed mainly by education and partly by family traditions.

Ecological products are known to both American and European customers, with some differences.

Discrepancies relate both to the legal aspects and to the offer addressed to customers. The aim of this article is to identify the differences between the availability of an organic product for an American and a Polish customer. Due to the realization of the objective, the hypothesis is that the legal regulation concerning the qualification of organic products does not affect the offer addressed to customers. 
An organic product is a specific type of product for which production requirements have been defined, however, specified properties have not. The advantage of organic products over their traditional counterparts is being discussed by scientists in the field of medicine and nature. To examine the differences in the qualification of agricultural products as an ecological analysis, the US and EU legal regulations were examined. The determinants of the purchase of the ecological product are described on the basis of the author's personal experience as a consumer.

\section{Legal regulation of organic products in the US and EU}

Organic products (based on the USA standards) are foods grown/produced by farmers who emphasize the use of renewable resources and the conservation of soil and water. Organic meat, poultry, eggs, and dairy products come from animals that are given no antibiotics or growth hormones. Organic food is produced without using most conventional pesticides; fertilizers made with synthetic ingredients or sewage sludge; bioengineering; or ionizing radiation. Organic farming systems rely on crop rotation, animal and plant manures, some hand weeding and biological pest control. Organic foods are products grown and produced based on the U.S Department of Agriculture (USDA, 2016) standards and regulations.

Organic products (based on the EU standards) are foods grown in a sustainable way. Livestock is raised in a free-range and an open-air environment and they are treated according to enhanced animal welfare conditions. Genetically modified organisms are not allowed in organic agriculture. There are strict limitations to the use of conventional pesticides, synthetic fertilizers, antibiotics and other substances. Organic farming systems rely on crop rotation and the input for farm production come from the farm itself by using local resources and local knowledge. Organic foods are products grown and produced based on the Council Regulation (EC) No 834/2007 of 28 June 2007 on organic production and labelling of organic products and repealing Regulation (EEC) No 2092/91, Article 37 (Official Journal of the European Union, 2011). Polish organic production is the subject of EU standards.

Conventional products are foods produced in conventional farming method that is not organic. Conventional method of production allows for using synthetic fertilizers, pesticides, antibiotics, hormones or genetically modified organisms to produce food. 
In 1991, in the context of EU farm policy reform, the European Council of Agricultural Ministers adopted Regulation (EEC) No 2092/91 on organic farming and the labelling of organic farm produce and foods. Initially it covered only plant products. Further rules on animal products were introduced later. The Commission Regulation (EC) No 889/2008 of 5 September 2008 is currently in force. It lays down rules for the implementation of Council Regulation (EC) No 834/2007 concerning detailed rules for organic production, labeling and control (Official Journal of the European Union, 2008). In 2002, those rules were adopted by the United States of America. The National Organic Standards implemented by the U.S. Department of Agriculture (USDA) took effect exactly on October 21, 2002. Products bearing the USDA Organic Label were supposed to meet the requirements of the Final National Organic Program (NOP) Rule governing the production, handling, processing, and labeling of organically grown food in the United States.

In February of 2012, the USA and the EU signed an agreement that allowed EU producers to sell organic foods, marked as organic, in the US and vice versa. According to regulation (EU) No 126/2012 (Official Journal of the European Union 2012) and this specific agreement, the control systems in the US were considered equivalent to those in the EU, yet there were some differences because the US and the EU did not employ identical standards. The 2012 agreement concluded that each jurisdiction would honor the "seal" awarded by the other and treat each other's standards as "equivalent". This agreement considers to be historic because not only it placed lots of emphasis on importing organic products but also focused on the variation in organic standards and criteria.

Organic foods in the USA are produced according to the USDA specified standards. They cannot be genetically modified, use synthetic fertilizers or pesticides in crop production, nor medicines such as antibiotics or growth hormones in animal production (USDA 2016). The EU organic production, which is governed by the European Commission on Agriculture does allow antibiotics for treatment of infected animals as well as the usage of conventional pesticides, synthetic fertilizers and other substances, even though they are governed by strict limitations (Official Journal of the European Union 2008).

The standards used to classify a product as organic haven't been equivalent. The absence of one, general level of impurities for organic food is noticeable. The specific level of pollution concerns only traditional food products. Organic farming only restricts the usage of pesticides to a small amount, and consumers generally expect organic food to have no impurities (European Food Safety Authority, 2011). Europe has legislation to control levels of pesticides in

VIOLETTA SKRODZKA 
foods, based on Maximum Residue Limits (MRL), however those levels differ throughout EU. Belgium has set a limit of 1.5 times the Limit of Quantification (LOQ) for most pesticides in organic foods. Italy calculates the limit of allowable pesticides in organics products based on $0.01 \mathrm{mg} / \mathrm{kg}$ for residues in all organic agricultural products. In contrast the US sets a maximum limit of 5\% (of the normal tolerance level for contaminants in conventional foods) as the level for organic foods.

\section{Ecological products versus conventional products}

Some studies suggest that changes in agricultural practices and the usage of chemically derived fertilizers and pesticides in agriculture, had a significant impact in nutrients composition of crops grown in a conventional way. Research conducted over the past 60 years on nutrient content in fresh fruit and vegetables grown traditionally in the United States and the United Kingdom has shown a decrease in the content of vitamins and minerals. Average declines in nutrient content are shown in table 1.

Table 1. Percentage decline in mineral content in conventional produce of U.S and British crops in the last sixty years

\begin{tabular}{l|l|l}
\hline Mineral & U.S. (13 fruits \& vegetables) & Britain (20 fruits and vegetables) \\
\hline Calcium & -29 & -19 \\
\hline Magnesium & -21 & -35 \\
\hline Sodium & N/A (not analyzed) & -43 \\
\hline Potassium & -6 & -14 \\
\hline Phosphorus & -11 & -6 \\
\hline Iron & -32 & -22 \\
\hline Copper & N/A (not analyzed) & -81 \\
\hline
\end{tabular}

Resource: Worthington 2001, pp. 161-173; Brandt, Leifert, Sanderson \& Seal 2011, pp. 177-197

V. Worthington (USA) had shown significant differences in the nutrient content of organic and conventional crops. She found that organic crops contained more vitamin C, iron, magnesium, and phosphorus and significantly smaller amounts 
of nitrates while compared to conventional crops. She also underlined that organic crops had less protein, however, these proteins were of a better quality. Moreover, organic fruits and vegetables were higher in essential minerals and lower in dangerous chemicals, heavy metals and pesticides (Worthington 2001, pp. 161-173). Similar findings on agricultural practices among organic and conventional farming and the usage of chemically derived fertilizers have been reported by K. Brandt et al. (UK). They showed that conventionally used fertilizers have a huge impact on plant composition by increasing availability of plant nitrogen, which can reduces an accumulation of defense-related secondary metabolites and vitamin $C$ and increase the contents of secondary metabolites such as carotenes, which are not involved in defense against disease. Brandt et al. showed that secondary metabolites and vitamin $\mathrm{C}$ in organic produce were $16 \%$ higher for defense-related compounds and 6\% higher for vitamin C (Brandt et al. 2011, pp. 177-197).

The publication of a systematic review of 137 studies by researchers from the London School of Hygiene and Tropical Medicine suggests that there is no sufficient evidence to substantiate the significant difference in nutrient content between traditionally and organically grown food. As the authors stated (Dangour et al. 2009, pp. 680-685) "On the basis of a systematic review of studies of satisfactory quality, there is no evidence of a difference in nutrient quality between organically and conventionally produced foodstuffs". A. D. Dangour and his coworkers claim that the minuscular difference in nutrient quality, found in the study can be related to biological plausibility as well as in the method of production. They detected no evidence of a difference in 8 of the 11 nutrient categories (table 2).

Table 2. Comparison of content of nutrients and other nutritionally relevant substances in organically and conventionally produced crops as reported in satisfactory-quality studies

\begin{tabular}{l|c|c|c|c|c}
\hline & & \multicolumn{2}{|c|}{ Results of analysis } & \multirow{2}{*}{$\begin{array}{c}\text { Higher concentrations in } \\
\text { organic or conventional } \\
\text { crops? }\end{array}$} \\
\hline $\begin{array}{l}\text { Nutrient } \\
\text { category } 1\end{array}$ & $\begin{array}{c}\text { No. of } \\
\text { studies }\end{array}$ & $\begin{array}{c}\text { No. of } \\
\text { comparisons }\end{array}$ & $\begin{array}{c}\text { Standardized } \\
\text { difference }\end{array}$ & $\boldsymbol{P}$ & $\%$ \\
\hline Nitrogen & 17 & 64 & $6.7 \pm 1.9$ & 0.003 & Conventional \\
\hline Vitamin C & 14 & 65 & $2.7 \pm 5.9$ & 0.84 & No difference
\end{tabular}

VIOLETTA SKRODZKA 


\begin{tabular}{l|c|c|c|c|c}
$\begin{array}{l}\text { Phenolic } \\
\text { compounds }\end{array}$ & 13 & 80 & $3.4 \pm 6.1$ & 0.60 & No difference \\
\hline Magnesium & 13 & 35 & $4.2 \pm 2.3$ & 0.10 & No difference \\
\hline Calcium & 13 & 37 & $3.7 \pm 4.8$ & 0.45 & No difference \\
\hline Phosphorus & 12 & 35 & $8.1 \pm 2.6$ & 0.009 & Organic \\
\hline Potassium & 12 & 34 & $2.7 \pm 2.4$ & 0.28 & No difference \\
\hline Zinc & 11 & 30 & $10.1 \pm 5.6$ & 0.11 & No difference \\
\hline $\begin{array}{l}\text { Total } \\
\text { soluble } \\
\text { solids }\end{array}$ & 11 & 29 & $0.4 \pm 4.0$ & 0.92 & No difference \\
\hline $\begin{array}{l}\text { Copper } \\
\text { Titratable } \\
\text { acidity }\end{array}$ & 11 & 30 & $8.6 \pm 11.5$ & 0.47 & No difference \\
\hline
\end{tabular}

Resource: Dangour A. D. et al. 2009, http://ajcn.nutrition.org/content/90/3/680/T1.expansion. html\#xref-fn-4-1 (12.06.2011 - access date)

Table 2 indicates that the biggest differences were noticed in the nitrogen content among conventionally grown produce and in titratable acidity and phosphorus among organically grown crops. They underline that "the significantly higher nitrogen content was most likely due to differences in fertilizer use (nitrogen and phosphorus) and titratable acidity was related due to the ripeness at harvest." (Dangour et al. 2009, pp. 680-685). The studies suggest that the results may be directly related to the ecological and conventional farming practices that caused the percentage decrease in vitamins and minerals. The authors of this particular study suggests that organic food does not contain special nutrients or pesticides, and its composition depends on the entire production cycle. This dependence on the production cycle while growing ecological food encourage conventional farmers to optimize their activities rather than obtain an ecological certificate. (Brandt et al., 2011, pp. 177-179; Worthington 2001, pp. 161-173).

The meta-analysis done by Stanford scientists, who reviewed 237 studies in which they compared organic and conventional foods, came across similar findings. The review concluded that "The published literature lacks strong evidence that organic foods are significantly more nutritious than conventional 
foods." They also did not find strong evidence that organic foods are more nutritious or carry fewer health risks than their conventional counterparts. The authors found that there were no significant differences in vitamin content, with an exception for phosphorus, which was higher in organic than in conventionally produced fruits and vegetables. According to this specific study, there is also no significant difference in fat or protein between organically produced milk, meats or eggs. The authors underlined, however, that organic produce had a 30 percent lower risk of pesticide contamination than conventionally produced crops (Smith-Spangler at al. 2012, pp. 348-366).

A review conducted by The Organic Center (OC) limited their study to plantbased foods and they found that among 11 nutrient measured, organic foods contained, on average, 25\% higher concentrations of nutrients (Benbrook, Zhao, et al, 2009). They also found that six of these eleven nutrients in the organic foods averaged $\geq 10 \%$ higher in organic foods. The conventional foods, on the other hand, were found to be higher $\geq 10 \%$ in protein.

M. Barański and his coworkers imply that not only organic foods but also products made out of them are healthier and more nutritious than their conventional counterparts. M. Barański et al. study was based on analyses of 342 peer review publications and concluded that organic products, while compared to their conventional counterparts, are higher in antioxidants, lower in certain toxins, including cadmium levels Also it was determined that organic grown crops are much lower in pesticide residues than conventionally grown fruits and vegetables. They established that conventional crops have as much as four times more pesticide residues than organic fruits and vegetables as Table 3 indicates (Barański at al. 2014, pp. 794-811). Similar findings about lower pesticide levels in organic versus conventional products were also found by A. D. Dangour (2009, pp. 680-685) and C. Smith-Spangler at al. . (2012, pp. 348-366).

It should be also pointed out that cadmium, besides lead and mercury is extremely toxic and the European Commission has established maximum residue levels (MRL). If over consumed, cadmium toxicity can cause not only conditions such bone softening or liver damage but also kidney failure and ultimately death (Barański, et al. 2014, pp. 794-811). According to the U.S. Environmental Protection Agency (EPA), 90\% of fungicides, $60 \%$ of herbicides and $30 \%$ of insecticides utilized for production of conventional foods are known to cause cancer. Other studies have shown that pesticides consumed in a form of residue on foods can lead to many different diseases such as cancer, obesity, diabetes, Parkinson's disease or infertility (Garber 2014). Young children 
are particularly at risk because of their weakened immune system. Therefore, scientific data suggests that people can reduce their exposure to pesticides by $80 \%$ if they switch from eating conventional to organic products when buying fresh produce (Garber 2014). Regardless of the research, consumers have positive attitude towards organic food. Subjective assessments show that it is perceived as healthy, safe, and trustworthy.

Table 3. Comparison of varies nutrients and toxins among organic and conventional crops

\begin{tabular}{l|l}
\hline Organic Crops & Conventional Crops \\
\hline $\begin{array}{l}\text { Higher antioxidant activity in organic crops (fruits): } \\
\text { Phenolic Acid 19\% higher }\end{array}$ & $\begin{array}{l}\text { Lower levels of antioxidant in conventional } \\
\text { fruits } \\
\text { Flavanones } 69 \% \text { higher }\end{array}$ \\
$\begin{array}{l}\text { Stilbenes } 28 \% \text { higher } \\
\text { Flavones } 26 \% \text { higher } \\
\text { Flavonols 50\% higher } \\
\text { Anthocyanins 51\% higher }\end{array}$ & \\
\hline Lower pesticide residues & \\
\hline Lower use of total nitrogen (N) and phosphorus (P) & Higher use of nitrogen $(\mathrm{N})$ and phosphorus $(\mathrm{P})$ \\
\hline $\begin{array}{l}\text { Lower concentrations of the toxic metal cadmium } \\
(\mathrm{Cd}, 48 \% \text { lower) }\end{array}$ & Higher concentrations of the toxic metal Cd \\
\hline
\end{tabular}

Source: Self-analyses by Barański at al. 2014, pp. 794-811

\section{Offer of organic agricultural products in Poland and USA}

The food market is adapted to the needs of local communities. In the United States, the population obtains supplies in large food markets that are known and recognized in most states. They are present in both large cities and smaller towns. Next to them there are small grocery stores offering products of foreign origin in large urban agglomerations. They usually cater for customers of a particular nationality preferring food from their country of origin. Their choice is based on sentiment and culinary habits. On the territory of Poland, there is a significant network of large stores and small grocery stores. Both of them exist in large and small populations clusters. 
Currently organic agricultural products are a permanent part of the offer of all US markets. A dozen or so years ago, organic food was only available at selected sellers. Ecological products are not present customarily in small grocery stores that cater for national needs. This is probably dictated by economic considerations. On the Polish market, ecological products are available at small points of sale of organic food and in selected supermarkets. Local grocery stores and supermarkets located in smaller towns do not have organic food in their offer.

On the American market there is a variety of organic products. The customer can buy both unprocessed and highly processed organic products. All equivalent of conventional products are available here. In Poland, the range of organic food is quite poor. It is dominated mainly by unprocessed or less processed food. Vegetables, fruit, eggs and bread are the most commonly purchased products. In the offer of Polish shops there is a significant share of foreign products from the category of processed food, but it is used in Polish cuisine only occasionally.

Another factor that determines the availability of organic products is their price. Both the US and Polish market prices of organic products are higher than their conventional equivalents. American customers pay for domestic organic products from $20 \%$ to $30 \%$ more than for traditional food in most stores. Imported products (for example maple syrup, olive oil, meat from Argentine) tend to be $100 \%$ more expensive. Price differences between organic and traditional food are much higher in Poland, where ecological products cost three or four times more.

The availability of organic products on the Polish and American markets is also determined by their location on the stores shelves. In American stores organic food is set in separate segments next to traditional food, with a clear indication that it is an organic product. In addition, ecological products have distinctive price tags. The location of organic products in Polish shops (except for organic food stores and a few supermarkets) is different. Ecological products are placed between traditional products. Their quest requires reviewing all the products of this type. The differences in availability of organic products in the US and Poland are presented in table 4.

Polish consumers have limited access to organic food products compared to American consumers. Fourteen years ago American organic food market was close to the current one in Poland. When analyzing the changes taking place in Poland and the US from the perspective of the customer, it can be stated that the availability of organic products is growing from one year to another. With the socio-economic development, the Polish market of organic products is moving towards a model developed in the USA. 
Table 4. Determinants of the availability of ecological products for a customer

\begin{tabular}{|c|c|c|}
\hline Specification & US market & Polish market \\
\hline Shops supply offer & $\begin{array}{l}\text { Organic products are available in } \\
\text { almost all food stores }\end{array}$ & $\begin{array}{l}\text { Ecological products are available in } \\
\text { selected grocery shops. }\end{array}$ \\
\hline $\begin{array}{l}\text { Visibility of organic } \\
\text { products against } \\
\text { conventional products }\end{array}$ & $\begin{array}{l}\text { The quest for organic products } \\
\text { does not cause difficulties in } \\
\text { American stores. They are in } \\
\text { separate sections, clearly labeled } \\
\text { as organic products or with } \\
\text { distinctive price tags on store } \\
\text { shelves. }\end{array}$ & $\begin{array}{l}\text { In some shops there are separate } \\
\text { sections with specific organic } \\
\text { products. Customers look for } \\
\text { organic products among traditional } \\
\text { products in most shops. }\end{array}$ \\
\hline Household Wealth & $\begin{array}{l}\text { American households are } \\
\text { diversified in terms of income. } \\
\text { The amount of income limit or } \\
\text { motivate to buy organic products. }\end{array}$ & $\begin{array}{l}\text { Polish households are diversified } \\
\text { in terms of income. The amount } \\
\text { of income limit or motivate to buy } \\
\text { organic products. }\end{array}$ \\
\hline Customer awareness & $\begin{array}{l}\text { Americans are aware of the } \\
\text { benefits of consuming organic } \\
\text { products. }\end{array}$ & $\begin{array}{l}\text { Polish society is aware of the } \\
\text { benefits of consuming organic } \\
\text { products. }\end{array}$ \\
\hline $\begin{array}{l}\text { Selection of organic } \\
\text { products. }\end{array}$ & $\begin{array}{l}\text { Most or almost all organic } \\
\text { products equivalent can be } \\
\text { found in such stores as Whole } \\
\text { Foods Market, Sprauts Farmers } \\
\text { Market, Natural Grocers, King } \\
\text { Sooper's, Safeway. Selected } \\
\text { ecological products are found } \\
\text { in convenience stores such as } \\
\text { Walmart }\end{array}$ & $\begin{array}{l}\text { The range of organic products } \\
\text { is diverse. Many, but not all, } \\
\text { traditional food equivalent are } \\
\text { found in organic food stores and } \\
\text { a few supermarkets (for example } \\
\text { Piotr i Paweł). Lidl offers a wide } \\
\text { range of vegetables, fruit and bread. } \\
\text { In other markets such as Biedronka, } \\
\text { Kaufland, Tesco and Auchan, } \\
\text { ecological products can be bought } \\
\text { sporadically or occasionally. }\end{array}$ \\
\hline Visual impressions & $\begin{array}{l}\text { Ecological vegetables and fruit } \\
\text { look unfavorable compared } \\
\text { to traditional products. Other } \\
\text { organic products look better } \\
\text { than traditional equivalent (for } \\
\text { example meat) or the same (flour, } \\
\text { sugar). }\end{array}$ & $\begin{array}{l}\text { Both organic vegetables, fruit and } \\
\text { other organic products look like } \\
\text { conventional products. }\end{array}$ \\
\hline
\end{tabular}




\section{Conclusion}

The standards used to recognize a product as organic are not identical in the US and EU countries. More stringent regulations are imposed on organic food producers in the USA. Despite the differences, the United States and the EU countries are mutually respecting the established rules for the qualification of organic products in the framework of trade exchange.

The comparison of organic and conventional food is very difficult. For decades, scientists from different countries have been trying to prove the superiority of an organic product over a conventional product, by examining the nutrients and their effects on human health. Although the published results and conclusions are quite equivocal they clearly define a lower content of toxins and pesticides in organic products. Regardless of the conducted research, consumers perceive organic food as healthy, safe and distinctive with high nutritional value.

Polish consumers, although interested in organic products, have a weaker position on the food market. American customers advantage lies in the availability of the organic products. Supply offer, variety and price are just some of the factors that determine the availability of organic food. The dynamic development of organic food trade partly eliminate unfavorable restrictions. Organic food access improvement is becoming an inherent part of more and more complex expectations of modern customers.

\section{Summary}

\section{Organic agricultural products in Europe and USA}

In the most developed countries of Western Europe and North America, the share of organic farming in the food market is between $2 \%$ and $6 \%$. The share of organic products on the Polish food market is only $0.33 \%$ (Dryjańska E. 2017). The aim of this article is to compare organic agricultural products in the US and EU. The scope of the comparison was covered by the legal regulations for organic production in the mentioned regions and the availability of organic products for customers. In order to highlight differences between the organic product and their traditional counterpart, selected meta-analyzes were conducted by authors in the field of medical and natural sciences. The possibilities of buying organic products are described on the basis of personal experiences of the author as a consumer. The offer of organic products was analyzed on the example of one European country (Poland) and 
the example of several states of America (Colorado, Virginia, New York). The rules for producing organic food in the US are more rigorous than in the EU. The offer of organic and conventional food targeted to the American consumer is comparable. Although Polish consumers have a positive perception of organic food, its supply is significantly different from the US market. The main differences are in distribution channels, product range, price and visual design of organic products.

Keywords: organic products, ecological products standards in the EU and US, research on organic food.

\section{Streszczenie}

\section{Organiczne produkty rolnicze w Europie i USA}

W najbardziej rozwiniętych krajach Europy Zachodniej i w Ameryce Północnej udział produktów rolnictwa ekologicznego w całym rynku spożywczym wynosi od 2 do 6\%. Udział produktów ekologicznych na polskim rynku żywnościowym zajmuje zaledwie 0,33\% (Dryjańska E. 2017). Celem artykułu jest porównanie ekologicznych produktów rolniczych w USA i UE. Zakresem przedmiotowym porównania objęto regulacje prawną dotyczącą produkcji ekologicznej $\mathrm{w}$ wymienionych regionach oraz dostępność produktów ekologicznych dla klientów. Dla podkreślenia różnic między produktem ekologicznym i ich tradycyjnym odpowiednikiem posłużono się wybranymi metaanalizami prowadzonymi przez autorów z obszaru nauk medycznych i przyrodniczych. Możliwości zakupu produktu ekologicznego opisano na podstawie doświadczeń osobistych autora jako konsumenta. Ofertę produktów ekologicznych analizowano na przykładzie jednego kraju europejskiego (Polska) oraz przykładzie kilku stanów amerykańskich (Colorado, Virginia, New York). Zasady produkcji żywności ekologicznej w USA są bardziej rygorystyczne niż w UE. Oferta żywności ekologicznej i konwencjonalnej kierowanej do konsumenta amerykańskiego jest porównywalna. Chociaż polscy konsumenci pozytywnie postrzegają żywność ekologiczną to jej podaż znacząco odbiega od rynku amerykańskiego. Główne różnice dotyczą kanałów dystrybucji, asortymentu, ceny oraz wizualnego oznaczenia produktów ekologicznych. 


\section{Słowa}

kluczowe: produkty ekologiczne, normy produktów ekologicznych w UE i USA, badania nad żywnością ekologiczną.

\section{JEL}

\section{Classification: L510, Q020, Q500, 0120}

\section{References}

1. Barański M., Średnicka -Tober D. et al. (2014), Higher antioxidant and lower cadmium concentrations and lower incidence of pesticide residues in organically grown crops: a systematic literature review and meta-analyses, "British Journal of Nutrition", Vol. 112 (5), pp. 794-811 doi:10.1017/S0007114514001366

2. Bourn D., Benbrook C., Zhao X., Yanez J., Andrews P. (2008), New evidence confirms the nutritional superiority of plant-based organic foods, The Organic Center State of Science Review, http://www.organic-center.org/science.nutri. php?action=viewEreport_id=126 (15.092017 -accessed date).

3. Brandt K., Leifert C., Sanderson R. \& Seal C. J. (2011), Agroecosystem Management and Nutritional Quality of Plant Foods: The Case of Organic Fruits and Vegetables, "Critical Reviews in Plant Science", No 30, pp. 177-197. DOI: $10.1080 / 07352689.2011 .554417$

4. Dangour, A.D., Dodhia S.K., Hayter A., Allen E., Lock K., Uauy R. (2009), Nutritional quality of organic foods: a systematic review, "Am J Clin Nutr.", Vol. 90, No. 3 , pp. 680-685.

5. Dryjańska E. (2017), Rynek i dostępność żywności ekologicznej w Polsce, ODR w Poznaniu, http://wodr.poznan.pl/baza-informacyjna/srodowisko/ rolnictwo-ekologiczne/zasasdy-etykietowania-produktow-ekologicznych / item/7470-rynek-i-dostepnosc-zywnosci-ekologicznej-w-polsce (5.11.2017 -accessed date).

6. Garber L. (2012), 7 Nasty and Crazy Effects of Pesticides in Food, Exposure, "Natural Society", http:/ / naturalsociety.com/7-nasty-effects-of-pesticidesin-food-exposure/ (1.08.2017- access date).

7. European Food Safety Authority (2011). The 2009 European Union report on pesticide residues in food, "EFSA Journal", No 9 (11): 2430.

8. National Organic Program (2016), U.S Department of Agriculture, http:// www.ams.usda.gov/nop/Consumers/brochure.html (12.09.2017- access date).

9. Comision Regulation (EC) No. 834/2007 of 28 June 2007 on organic production and labelling of organic products and repealing Regulation (EEC) No. 2092/91. (Official Journal of the European Union, L 156/12 of 15.06.2011).

10. Comision Regulation (EC) No 889/2008 of 5 September 2008 laying down detailed rules for the implementation of Council Regulation (EC) No 
$834 / 2007$ on organic production and labelling of organic products with regard to organic production, labelling and control (Official Journal of the European Union, L 250 of 18.09.2008).

11. Comision Regulation (EU) No 126/2012of 14 February 2012 amending Regulation (EC) No 89/2008 as regards documentary evidence and amending Regulation(EC) No 1235/2008 as regards the arrangements for imports of organic products from the United States of America (Official Journal of the European Union, L 41/5 of 15.02.2012).

12. Smith-Spangler C., Brandeau M.L., Hunter G.E., Bavinger J.C., Pearson M., Eschbach P.J., Sundaram V., Liu H., Schirmer P., Stave C., Olkin I., Bravata D.M. (2012), Are organic foods safer or healthier than conventional alternatives?: a systematic review “Ann Intern Med." No. 157(5), pp. 348-366, doi: 10.7326/0003-4819-157-5-201209040-00007.

13. Worthington V. (2001), Nutritional Quality of Organic Versus Conventional Fruits, Vegetables, and Grains "The Journal of Alternative and Complementary Medicine" Vol. 7, No. 2, pp. 161-173. 